\title{
ECONOMIC IMPACTS OF THE CONSERVATION RESERVE PROGRAM ON RURAL ECONOMIES
}

\author{
Bengt T. Hyberg, Michael R. Dicks, and Thomas Hebert*
}

\begin{abstract}
The impacts of a substantial program like the CRP, while significant for the nation, are potentially even more important for local farm dependent economies. This paper illustrates the importance of measuring the distributional impacts of national programs. The impacts of the CRP on 5 industrial sectors were investigated at national, regional, and local levels using an input/output model. The results indicate that the agricultural production sector is most affected, followed by the agricultural inputs sector. The Total Gross Output (TGO) in the agricultural production sector and the agricultural inputs sector in areas dependent on agricultural production were found to decline up to 7 times the national rate. TGO for agriculturally dependent, rural economies decreased up to 35 times the national rate.
\end{abstract}

\section{INTRODUCTION}

The economic and employment links between agriculture and the industries supplying its inputs (upstream) and processing its output (downstream) determine how a change in the agricultural sector will affect the rest of the economy. While minor changes in farm programs (such as temporarily reducing commodity acreage or production to limit Government stock accumulation) have a limited long-term effect on employment and income in the rest of the economy, substantial changes in farm programs, such as the Conservation Reserve Program (CRP) affect the entire economy by forcing cutbacks in industries linked either directly or indirectly to agricultural production while inducing changes in household consumption industries [Harrington, Schluter and O'Brien (1986)].

The importance of agriculture in the U.S. economy is indicated by noting that agricultural production, consumption, and trade accounts for approximately 18 percent of the U.S. Gross National Product and results in 21.3 million jobs. While crop and livestock production activities accounted for only 2 percent of the Gross National Product (GNP) and 2.7 million jobs in 1984 [Harrington, Schluter and O'Brien (1986)], the activities associated with supplying inputs for the production of agricultural commodities accounted for an additional 2 percent of

\footnotetext{
*Agricultural Economist, Economic Research Service; Assistant Professor, Oklahoma State University; and Economist, Senate Agricultural Committee. The views expressed in this paper are the authors' and do not necessarily reflect those of the Economic Research Service or the United States Department of Agriculture. The authors thank Fred Hines, David Henderson, Judith Sommer, Mindy Petrulis, Thomas Johnson, Ian McCormick, Ken Algozin, and two anonymous reviewers for their useful comments.
} 
GNP and 2 million jobs, and an additional 14 percent of GNP and 16.6 million jobs were attributable to the downstream activities associated with agriculture. These statistics indicate that federal agricultural or resource policy, while directly affecting agriculture and therefore only 2 percent of the nation's economy, can indirectly affect approximately 21 million jobs and 18 percent of GNP.

The size of the potential economic impacts of federal agricultural policy increases as the importance of agriculture in the area considered increases. A 1984 study of agriculture in Colorado illustrates the importance of agriculture to local economies. Miller et al. (1987) found that while crop and livestock production activities accounted for only approximately 2 percent of Colorado's total income, in the 15 farm dependent counties, where farm income and employment make up more than 20 percent of county income and employment [Bender et al. (1985); Petrulis, et al. (1987)], crop and livestock activities alone accounted for 51 percent of the counties' total income. The food system accounted for 69 percent of total employment in these counties. In a second group of 10 counties, where farm income and employment make up more than 10 percent of the counties' income and employment, 27 percent of total income and 45 percent of employment was attributable to the food system. Data from 1975-79 for Montana indicates a large number of counties in a similar farm dependent situation [Petrulis et al. (1987), p 10)]. The farm dependent and important counties in both states will be significantly affected by any farm policy such as the CRP that displaces a considerable portion of crop production and economic activity generated through agricultural production.

The impacts of a substantial program like the CRP, while significant for the nation, are potentially even more important for farm dependent economies in the Mountain states (Arizona, Colorado, Idaho, Montana, New Mexico, Nevada, Utah, and Wyoming), since 43 percent of the region's total cropland is eligible for the CRP and 51 percent of the eligible acreage has been enrolled in the program. This paper illustrates the importance of measuring the distributional impacts of national programs. Emphasis is placed on comparing the economic impacts of the program on farm dependent areas, states and regions. Specific examples are drawn from areas within the Mountain Region that have a high proportion of their cropland acreage enrolled in the CRP.

\section{THE CONSERVATION RESERVE PROGRAM (CRP) AND FARM DEPENDENT COMMUNITIES}

The CRP is a ten year Federal acreage reduction program that will ultimately remove approximately 45 million acres of fragile cropland from agricultural 
production. Although the primary goal of the program is to reduce soil erosion on highly erodible agricultural land, the program will also reduce the production of surplus agricultural commodities that are eligible for Federal commodity program payments and benefits. The CRP involves a ten-year agreement between the Federal government and a farmer/landowner. To enter the program a farmer agrees to place the land removed from production into an approved conservation practice for ten years. The government in turn, agrees to pay the farmer an annual rental payment and half the cost of the conservation practice's establishment. The program began in 1986, and by July 1987 approximately 23 million acres had been enrolled.

Only a little over seven percent of total U.S. cropland is enrolled in the CRP. While more than 75 percent of the counties have participated in the program, 80 percent of the land is concentrated in only 25 percent of the participating counties. The counties with high rates of participation tend to be concentrated in specific regions of the country. The majority of these counties are located in the Mountain and Southern Plains (Texas and Oklahoma) regions, with the greatest concentration of counties with high levels of enrollment occurring in the high plains areas in Texas, New Mexico, Oklahoma, Kansas, Colorado and Montana. Enrollment is highly concentrated because of the large quantity of eligible cropland in certain counties where annual CRP rental payments greatly exceed the opportunity cost of the land. 1

The impacts that the program will have on those areas of the Mountain and Plains states with high levels of enrollments will depend upon the actual level of CRP participation, the level of crop production control achieved, the expenditures generated by the rental and establishment cost-share payments, and the local economy's ability to adapt to changes in the local expenditure patterns.

Before presenting the estimates of the economic impacts of the CRP, the methods used to estimate the regional and local CRP acreage and model the local economies will be described. The impacts of the CRP on rural economies are highlighted by comparing the impacts of the program on the nation as a whole to those for ten regions of the country including the Mountain region, and three areas within the Mountain region: the state of Montana, Northeastem Montana and Southeastern Colorado.

\section{METHODS}

The distribution of the 23 million acres enrolled in the CRP as of 1987 was determined by aggregating individual observations from the Agricultural Stabilization and Conservation Service records at the county, farm production 
region, and national levels. Participation in the program was determined by crop for each geographic region studied. The distribution of the participation for a full enrollment of 45 million acres was estimated at a county level by using the trends in program enrollment. County enrollments for the 45 million acre program were constrained by the Food Security Act of 1985 requirement limiting a county's enrollment to 25 percent of its total cropland. Total enrollments in a region or county were also constrained by the number of eligible acres in the area.

To determine the effects of the CRP on local economies, the impacts must be traced from the reduction in crop production (direct impacts) through the reduction in the associated agricultural input and processing industries (indirect impacts), to the goods and services industries providing support to these agricultural industries (induced impacts). The USDA Forest Service has developed a computer-based system, IMPLAN, which utilizes input-output analysis procedures capable of estimating the inter-industry economic impacts [Miernyk (1965), Richardson (1972) and Miller and Blair (1985)].

The IMPLAN model data base contains a national technology matrix of industrial production functions [Alward and Palmer (1985)]. These production functions describe the 1982 purchase patterns between industries through the use of gross output, final demand and final payment measures for each of the industries. The data base collapses the total U.S. economy into 528 industrial sectors.

IMPLAN also contains county-level estimates of gross transactions for ten components of consumption, investment and trade demand, four value-added components, employment and total industry output. IMPLAN uses these estimates in conjunction with the national technology matrix of production functions to create county-level I/O models, or models of any desired aggregation of counties (including sub-state, state, and regional models). This method was used to create models for the areas analyzed in this study.

Before the impacts of enrolling highly erodible cropland in the CRP in these areas can be estimated, the CRP rental payments and changes in cropland use for these areas is converted into changes in the final demand for feed grains, food grains, cotton, oil-bearing crops, hay, pasture and forestry establishment and household consumption activities [Dicks, et al. (1990)]. These changes in final demand are estimated by calculating the shift in production due to the CRP and evaluating the change in production in the base year (1982) prices. Each area's final demand changes are then imposed upon their respective IMPLAN model. The response coefficients used have been modified to represent the costs associated with the reduced production. Land rents and capital costs were held constant because they are fixed costs and not effected by the CRP [USDA (1990)]. 
The shocks caused by these changes in final demand will result in changes in the total gross output (TGO), and employment in all sectors. ${ }^{2}$

The approach used to examine the processing sector assumes there are sufficient grain stocks to offset the declining production due to the CRP. This assumption is supported by the fact that, although the 1988 drought reduced stock levels, total supply is still greater than total use. To the extent this assumption is in error, the effect of the CRP on the processing sector will be understated. The use of IMPLAN in this manner examines only the backward linkages between agricultural production and the processing sector.

The study also assumes the CRP did not increase commodity prices. To the extent this assumption is inaccurate, the effect of the CRP on local economies is overstated. The assumption is justified by the fact that in 1987 and 1988 (the last years for which data are available), only 13 million acres (18 percent) of the approximately 73 million acres idled under various land retirement programs were idled under the CRP. To correctly assess the impact of the CRP on crop prices, one would need to multiply the percent of acreage under the CRP by the price effect both with and without all government programs. However, the large annual quantity of acreage idled under all land retirement programs between 1986 and 1987 inhibits the determination of price impacts with and without all land retirement programs. Current econometric response coefficients (elasticities) for domestic and world demand are not adequate for this level of supply reduction. Calculating the marginal price impact of the CRP (with and without the CRP) overestimates the price effect of the CRP. Using such estimates would lead to an underestimate of the effects of the CRP on local economies.

Three separate stages of CRP final demand shocks, reflecting changes in the program requirements over time, are imposed on the models. The first, or cover establishment, stage imposes the final demand changes associated with the 23 million acres enrolled as of July, 1987, where establishment activities are taking place and rental payments are being received. The second, or full CRP, stage reflects the impacts of the CRP after all establishment activities have ended, and rental payments are received for the $\mathbf{4 5}$ million acres that have been enrolled nationally.

The third stage, or post-CRP period, contains two separate economic shocks. The shocks are modeled separately to highlight the effects of the rental payments relative to the cropland acreage removed from production. One shock occurring in the third stage comes from the ending of rental payments. The results of this shock are presented to emphasize just how important this acreage is to the local economy, particularly without the supplemental rental payments. The second shock modeled reflects what will happen in the local economies after the CRP has 
ended if one-half of the CRP grassland were used for commercial hay and pasture production.

Table 1 summarizes the stages of demand shocks. To interpret the results of the analysis, it is important to understand how the different shocks are treated in the model. The revenue from the receipt of rental payments goes into the household expenditure sector, because this revenue is assumed to be used for the maintenance of farm households. ${ }^{3}$ The TGO in the agricultural production sector is treated as the economic activity resulting from production of agricultural goods. Thus, the CRP will reduce economic activity in the agricultural production sector because it displaces farming activities with rental payments going into the household expenditures sector. The expenditures that once went to acquire seed, fertilizer, machinery, and hired labor for production on the land in the CRP are substituted for expenditures on private and public services, recreation, durables, and other household goods and services.

After the shocks were imposed on the national and regional models, the 528 industrial sectors were aggregated into 5 sectors: agricultural production, agricultural inputs, agricultural processing, household expenditures, and other industrial sectors. ${ }^{4}$ The aggregation results in some retail agricultural activity being merged into the other industrial sector, but the qualitative results are not altered. Aggregation of sectors simplifies the discussion, while capturing the fundamental results of the analysis.

\section{RESULTS}

\section{National Impacts of the CRP}

In all three stages, the CRP results in reduced regional and national economic activity due to the shocks to final demand described above. Total gross output and employment decrease nationally in all sectors (Table 2, more comprehensive appendix tables are available from authors upon request). The reduction in economic activity due to decreases in agricultural production and the related decrease in the use of agricultural inputs are somewhat offset by the temporary infusion of rental payments.

In stage 1, agricultural production total gross output and employment decrease as cropland is retired from production, rental payments are made to participants, and cover crops are established (Table 2). In the next stage, economic activity declines in all sectors. The agricultural input sector declines more rapidly in the second stage than is true in other sectors because the expenditures for cover establishment which stimulate the sector were completed in the first stage. As 


\section{TABLE 1}

The 3 Stages of the CRP

\section{Stage 1: 23 million acres with establishment activities}

- 23 million acres of cropland are diverted.

- Rental payments are made to farmers.

- Farm income and government funds are used to establish cover crop.

The establishment stage reduces agricultural production through the retirement of cropland. The lower agricultural production reduces the use of agricultural inputs, causes a decrease in farm income, and has a small impact on agricultural processing. The establishment stage also is characterized by the establishment of cover crops on the retired cropland. This activity decreases the farm income available for household consumption, and increases the payments to labor and agricultural inputs (but not enough to offset the reduction caused by the land retirement). A rental payment is also received by farmers in this stage. The rental payment increases the income available for household consumption.

\section{Stage 2: 45 million acres, no establishment activities}

- 45 million acres diverted.

- Rental payments are made to farmers.

During this stage the retired cropland remains idled and farmers continue to receive rental payments. Household incomes will increase slightly because no income will be diverted for the establishment of the cover crops.

\section{Stage 3: CRP contracts end, land can return to production}

- Rental payments end.

- Some cropland is assumed to remain out of production.

The full effect of the CRP is felt after the rental payments have ended. One-half of the CRP grassland is assumed to enter pasture and hay production. This production stimulates economic activity in the livestock industry, inducing effects throughout the regional economy. The re-entry of pastureland into production is included as a separate shock to permit the identification of the effects of the rental payments and production on the local economies.

would be expected, the reduction in economic activity that results from the ending of the rental payments in stage 3 is the largest of the shocks. The economic activity that results from returning some of the CRP land to production increases TGO in all sectors (Tables 2,3 , and 4). 
TABLE 2

Effects of CRP: Percent Change in National

Total Gross Output by Economic Sector

\begin{tabular}{lccccc}
\hline \hline & $\begin{array}{c}\text { Agricul- } \\
\text { tural } \\
\text { Inputs }\end{array}$ & $\begin{array}{c}\text { Agricul- } \\
\text { tural } \\
\text { Production }\end{array}$ & $\begin{array}{c}\text { Agricul- } \\
\text { tural } \\
\text { Processing }\end{array}$ & $\begin{array}{c}\text { Other } \\
\text { Manufac- } \\
\text { turing }\end{array}$ & $\begin{array}{c}\text { Household } \\
\text { Expendi- } \\
\text { tures }\end{array}$ \\
\hline $\begin{array}{l}\text { Total Gross Outputs } \\
\quad \\
\text { 1982 Level (Mil \$) }\end{array}$ & 26481 & 195890 & 421144 & 2630834 & 2697925 \\
& & & & & \\
23 Million Acres & -0.68 & -1.49 & -0.02 & -0.03 & -0.04 \\
45 Million Acres & -1.98 & -2.95 & -0.02 & -0.07 & -0.06 \\
Post-CRP, W/O Production & -2.25 & -3.09 & -0.18 & -0.15 & -0.22 \\
Post-CRP, W Production & -1.85 & -2.69 & -0.16 & -0.13 & -0.19 \\
\hline
\end{tabular}

The agricultural production sector is the most affected by the CRP (Table 2). The reduction in total gross output is approximately 3 percent nationally in the second stage. Some increase in economic activity can be expected after the contracts expire and the retired land goes into haying and grazing, but the level of activity will not recover to pre-program levels.

The reduction in cropland use decreases total gross output in the agricultural input sector (Table 2). This reduction occurs both during the program and after the rental payments have ended. The establishment of the cover crop mitigates the negative economic impact in the first stage, but over the remainder of the program economic activity in the input sector falls to a lower level.

Total gross output in the agricultural processing sector decreases nationally, although this decrease is marginal (Table 2). The percentage changes in the processing sector are small in comparison to other agricultural sectors because large stocks of agricultural commodities are assumed to be sufficient to permit the continuation of most processing activities. In addition, the rental payments in the Mountain States were large relative to the profits available from agricultural production resulting in an increase in the household expenditures sector. The increased household consumption expenditures partially offsets the negative effect of the decreased economic activity associated with a reduction in crop acreage. ${ }^{5}$

The CRP will have a minor impact on the economic activity in the household and other sectors. Total gross output and employment fall by one tenth of one percent in the household sector as the CRP rental payments serve to increase household consumption, but the overall decrease in household income decreases consumption. Total gross output and employment decrease even less in the other sectors of the economy (Table 2). 


\section{Local and Regional Impacts of the CRP}

The greatest impacts are found in regions with a large number of farm dependent counties and high rates of enrollment in the CRP. Larger impacts are observed in the Northern Plains, Southern Plains, and Mountain states due to high enrollment rates ( $44 \%$ of the eligible land).

The CRP reduces activity in the agricultural production sector in all regions. The effects on the agricultural production sector will be greatest in the Northern and Southem Plains, and the Mountain States. When smaller, more agriculturally dependent areas are examined, the CRP has an even greater effect on agricultural activity. Reductions in the agricultural production sector's TGO reach 2 percent in the Mountain Region, 3.7 percent in Montana, 3.9 percent in Southeastem Colorado, and 9.5 percent in Northeastern Montana in stage 1. These decreases nearly double with the 45 million acre CRP in stage 2 (Table 3 ).

Employment in the agricultural production sector decreases both during and after the CRP. While the CRP contracts are in effect in stage 2, the decreases in employment range from 3.5 percent in the Mountain Region to 21.4 percent in Northeastern Montana. Employment declined 11.3 percent in Montana and 5.9 percent in Southeastern Colorado. The impact of the CRP on employment in the agricultural production sector can be expected to diminish after the land retired from crop production goes into haying and grazing.

The regional and local effects on the agricultural input sector have a pattem similar to the production sector. The same areas feel the greatest impact. The negative effects of removing the CRP land from crop production on the input sector reflect the impacts nationally. The effects are mitigated during the first stage of the CRP because agricultural inputs are needed for the establishment of a cover crop. In stage 2, after the cover crop has been established, the sector's TGO in the Mountain states decrease approximately 3.1 percent. In agriculturally dependent rural areas such as Montana, Northeastern Montana, and Southeastern Colorado the effects of the CRP on the input sector are magnified. Stage 2 total gross output in the input sector for these areas decreases 8.2, 15.7, and 2.4 percent, respectively.

Generally, the effect of the CRP on the household and other economic sectors at a regional level are small in percentage terms. The results tend to indicate slightly reduced levels of income, total gross output, and employment. When the ratio of the annual rental payment to the cash rent for land is high, household income can actually increase. For example, in Montana and Northeastern Montana the rental payment is 1.6 times greater than cash rent for the land, and activity in the household expenditure sector increases during the period when payments are being received. 
TABLE 3

Effects of CRP: Percent Change in Total Gross Output in the Agricultural Production Sector, by Region

\begin{tabular}{lccrrr}
\hline \hline & Nation & $\begin{array}{c}\text { Mountain } \\
\text { States }\end{array}$ & Montana & $\begin{array}{c}\text { Northeast } \\
\text { Montana }\end{array}$ & $\begin{array}{c}\text { Southeast } \\
\text { Colorado }\end{array}$ \\
\hline $\begin{array}{l}\text { Total Gross Outputs } \\
\text { 1982 Level (Mil \$) }\end{array}$ & 195890 & 14370 & 2228 & 396 & 672 \\
& & & & & \\
23 Million Acres & -1.49 & -2.04 & -3.71 & -9.47 & -3.89 \\
45 Million Acres & -2.95 & -3.51 & -10.28 & -20.86 & -4.32 \\
$\begin{array}{l}\text { Post-CRP, W/O Production } \\
\text { Post-CRP, W Production }\end{array}$ & -3.09 & -3.60 & -10.51 & -21.01 & -4.42 \\
\hline
\end{tabular}

The existence of alternative economic opportunities in an area affects the impact of the CRP on a region's economy. The total economic impact of the CRP on Southeastern Colorado, which includes two metropolitan areas and has a large military influence, is much smaller than for Montana and Northeastern Montana (Table 4). This smaller impact occurs even though Southeastem Colorado has a significant proportion of its cropland acres enrolled in the CRP. Nationwide, the decline in TGO for all sectors under the second stage is 0.17 percent, while for Northeastern Montana, a much less diversified economy, the decrease is more than 36 times greater ( 6.24 percent).

As the CRP approaches $\mathbf{4 5}$ million acres nationally, the number of acres enrolled in a local area increases exacerbating the decline in economic activity in regions such as Montana, while barely affecting other regions such as Southeastem Colorado (Table 4). The difference stems from the fact that Southeastem Colorado, as of 1987 , had already nearly reached the maximum enrollment permitted by the Food Security Act. Montana, on the other hand, has a substantial amount of cropland that could still enter the CRP.

The results suggest that the CRP will have little impact on the agricultural processing sector during the period when rental payments are made, provided stock levels remain high. Rental payments, which are essentially ordinary disposable income, are used by farmers to purchase a bundle of goods that includes a large component of these high-valued processed agricultural goods. As a result, the economic activity in the agricultural processing sector can increase as rental payments and disposable farmer incomes increase, even when planted crop acreage is reduced, because the rental payments more than offset the loss in employment in the agricultural inputs and agricultural production sectors.

If stock levels were reduced and no longer sufficient to fill processing needs, reduced agricultural output would also lower the regional grain handling and 
TABLE 4

Effects of CRP: Percent Change in Total Gross Output Over all Sectors, by Region

\begin{tabular}{lccccc}
\hline \hline & Nation & $\begin{array}{c}\text { Mountain } \\
\text { States }\end{array}$ & Montana & $\begin{array}{c}\text { Northeast } \\
\text { Montana }\end{array}$ & $\begin{array}{c}\text { Southeast } \\
\text { Colorado }\end{array}$ \\
\hline $\begin{array}{l}\text { Total Gross Outputs } \\
\quad \text { 1982 Level (Mil \$) }\end{array}$ & 5972275 & 307727 & 18530 & 1268 & 10231 \\
& & & & & \\
23 Million Acres & -0.09 & -0.10 & -0.43 & -3.01 & -0.25 \\
45 Million Acres & -0.17 & -0.18 & -1.17 & -6.24 & -0.28 \\
$\begin{array}{l}\text { Post-CRP, W/O Production } \\
\text { Post-CRP, W Production }\end{array}$ & -0.29 & -0.35 & -2.22 & -9.64 & -0.48 \\
& -0.25 & -0.31 & -1.88 & -8.28 & -0.44 \\
\hline
\end{tabular}

marketing activities (see footnote 5). Nationally, if stocks decreased and sufficient grain was not available, the agricultural processing sector would be affected, but grain would be imported to maintain the high-value processing activities. The grain handlers and marketers in port areas and regions containing high value processing activities would be affected.

\section{ASSUMPTIONS}

The analysis presented above relies on strong assumptions that define the source of the rental payments, the pattern of household consumption, the movement of resources between sectors, and the effects of inter-regional trade. This section discusses these assumptions and the impacts that they have on the results. The CRP rental payments are transfer payments from taxpayers to program participants and will have economic impacts through changes in both farmer and taxpayer disposable incomes. For this analysis the rental payments are not treated as transfers but are assumed to enter the economy exogenously. The results therefore do not reflect the reduction in income and therefore economic activity that will result from the taxation that makes the CRP possible, and in tum overstate the positive impacts of the rental payments at both the national and regional level. The impacts of ignoring taxation are further complicated by the redistribution of wealth from region to region. Some regions with large populations, large incomes and relatively small levels of CRP participation may pay more in taxes than they receive in CRP payments, thereby experiencing a net decline in disposable income as a result.

The analysis also assumes that the rental payments are made to persons living in the same areas as where the land is retired. In some communities a proportion of the participants in the CRP are nonresident landowners or leave the 
area after retiring their cropland. As a result, the CRP rental payments made to these participants do not contribute to economic activity in the community. By assuming that 100 percent of the payments are made to residents, the positive effects of the payments on local economic activity are probably overstated.

Household consumption expenditures were fueled by the receipt of CRP rental payments. These expenditures were assumed to be a constant portion of income consistent with the historical expenditure patterns of residents earning an average income for the region. Because there are no data available on the income levels of CRP participants or participants' spending patterns, the assumption of average incomes and constant expenditure patterns is a reasonable first approximation. ${ }^{6}$ If, as additional information is obtained, the incomes of recipients of CRP rental payments are found to differ from the regional average, or the assumed spending patterns deviate from historical patterns, the impacts of the CRP will have to be re-estimated. The household expenditures sector would be most affected by any adjustment in the assumptions, but the changes would be felt in all sectors.

The analysis assumes that the local economies are not able to reallocate available resources between the agricultural and non-agricultural sectors. In reality, the movement of land, labor, and capital between the different sectors will require an adjustment period, as individuals are trained, land exchanged, and capital reallocated. Such an adjustment can be expected to take place over a period of years. The results presented here are abstractions that portray the changes as resources no longer employed. This does not permit the display of the adjustments that occur during the transition period, but identifies the instantaneous effects of the changes in land use.

A regional model estimates the effects of CRP participation from only that region, the assumption being that there is no inter-regional trade. The effects on one region of the reduction in crop acreage in adjoining regions are therefore not included in this analysis. For example, the farm implement manufacturers in the Corn Belt produce equipment for sale throughout the country, and the removal of national acreage from crop production may reduce these manufacturers' national sales and their manufacturing activity. By ignoring the acreage reductions in other regions, the model underestimates the CRP impacts on these farm implement manufacturers, and therefore the impacts on the Corn Belt's total economic activity.

\section{SUMMARY}

The Conservation Reserve Program represents a substantial change in U. S. agricultural policy. The CRP will have only a minor effect on the nation's 
economy and agricultural production, but it will lead to a substantial reduction in economic activity in a number of agriculturally dependent economies. The greater impact of the CRP on agriculturally dependent economies is explained by observing that the eligibility requirements and agricultural nature of the CRP serve to focus the effects of the program on rural economies with large amounts of marginally productive, highly erosive land.

As the concentration of enrollment in the CRP and the dependence on agriculture increase, the effects of the CRP also increase. The Northern Plains, Southern Plains, and the Mountain States are the production regions that feel the largest effects of the program. Rural communities within these regions are affected to an even larger degree, with the total gross output in some regions decreasing more than 35 times the national figure.

Although rental payments are made to landowners for their retired cropland, implementation of the CRP reduces agricultural production enough to cause economic activity to decline. Total gross output and employment decrease nationally in all regions and sectors. The agricultural production and inputs sectors are most affected by the CRP. The household expenditure and other sectors are affected, but only marginally. Increasing the number of acres enrolled in the CRP from the 23 million currently enrolled to 45 million acres will double the decline in national economic activity, but will affect the local economies differently.

The effects of the CRP suggest the distributional consequences of conservation programs need to be carefully considered prior to implementing the program. This study demonstrates that national programs targeting environmentally sensitive areas can have an undesired impact on local economies. While environmental programs may free resources that could be used more efficiently, these uses may be located in other communities. Successful implementation of environmental legislation requires an analysis of the distributional effects of these programs to assure rural communities are not inadvertently bearing an unfair portion of the costs.

\section{ENDNOTES}

1. It might be argued that the accumulation of agricultural surpluses requires a land retirement program to restrain agricultural production. This argument holds that without the CRP a stronger set-aside program would have been imposed.

There are several factors that must be considered when examining this contention. First, the acreage reduction program and paid land diversion requirements under the Food Security Act are near or at historical highs making it politically difficult to legislate stronger set-aside requirements. In addition, while the Moun- 
tain States accounted for only 8 percent of the com, sorghum, wheat, and cotton acreage harvested during 1987 (11.1 million acres of 135.6 million acres harvested nationally), this region provided 20 percent of the 25.5 million acres of land enrolled in the CRP as of February 1988. Given the uncertainty concerning a stronger set-aside requirement, and the disproportionate CRP enrollment in the Mountain States it is reasonable to estimate the economic effect of the CRP on the Mountain States and communities within the region, by examining the economic activity foregone by retiring land into the CRP.

2. Employment in IMPLAN is a mix of full and part time employment. Input-output models often use full time employment equivalents [Alward and Palmer (1985)].

3. This assumption is a logical extension of the CRP bidding process. Because the farmers enter a voluntary bid for admission into the program, the bid should compensate the farmer for the foregone profits from agricultural production. The profits from agricultural production would have been used by the farmer for the maintenance of the household.

4. Agricultural Production includes all crop and livestock activities. Agricultural Inputs includes farm machinery, chemical and fertilizer inputs. Agricultural Processing includes the primary handlers of grains and livestock, and all of the secondary handlers and manufacturers of high-value products (i.e., breakfast foods, frozen dinners, and fruit and vegetable processed products). The Other Industrial sector includes all non-agricultural manufacturing and services, while the Household Expenditures sector includes all of the activity associated with the expenditures of personal income. Total, is the sum of all 5 sectors.

5. The processing and household expenditure sectors are affected in two ways. First, the reduced agricultural production results in a loss of income in the agricultural production and inputs sectors. This reduced income feeds back into the processing and household sectors causing reduced economic activity in these sectors. On the other hand, the rental payments go directly into the household expenditures sector, encouraging increased household consumption. The increased consumption results in increased demand for processed goods including food. These two effects tend to offset each other.

6. Henderson, et al. (1989) have found evidence that as per capita farm income increases in small rural communities, the proportion of household expenditures spent in larger communities increases. This result suggests that the use of historical expenditure patterns may understate the effect of the CRP on small rural communities. 


\section{REFERENCES}

Alward, G. and C. Palmer. Implan User's Guide, Version 1.1. Ft. Collins, Colorado.: U. S. Forest Service, 1985.

Bender, Lloyd D., Bernal L. Green, Thomas F. Hady, John A. Kuehn, Marlys K. Nelson, Leon B. Perkinson, and Peggy J. Ross. The Diverse Social and Economic Structure of Non-metropolitan American. Rural Development Research Report \#49. Washington, D.C.: Economic Research Service, 1985.

Dicks, M., B. Hyberg, T. Hebert. An Inter-Industry Model for Estimating the Impacts of Cropland Diversion: A User's Guide. Washington, D.C.: Economic Research Service, Forthcoming 1990.

Harrington, D., G. Schluter, and P. O'Brien. Agriculture's Links to the National Economy: Income and Employment. AIB \#504. Washington, D.C.: Economic Research Service, 1986.

Henderson, D., L. Tweeten, and D. Schreiner. Intra-Regional Development: Agricultural and Nodal Adjustment in Oklahoma's Southern High Plains. Regional Science Perspectives. 5 (1989). 31-35.

Miernyk, W. H. The Elements of Input-Output Analysis. New York, N.Y.: Random House, 1965.

Miller, Ronald E. and Peter D. Blair. Input-Output Analysis: Foundations and Extensions. Englewood Cliffs, N.J.: Prentice-Hall, Inc., 1985.

Miller, T., L. Gray, and W. Trock. "Colorado's Farm and Food System: Economic Contributions to Rural and Metropolitan Counties." DARE Research Report AR:87-5. Ft. Collins, Colorado.: Colorado State University, 1987.

Petrulis, M., B. Green, F. Hines, R. Nolen, and J. Sommer. How is Farm Financial Stress Affecting Rural America? AER \#568. Washington, D.C.: Economics Research Service, 1987.

Richardson, H. W. Input-Output Analysis and Regional Economics. New York, N.Y.: John Wiley and Sons, 1972.

U. S. Department of Agriculture. Agricultural Resources: Agricultural Land Values and Markets. AR-18. Washington, D.C.: Economic Research Service, 1990. 